Prace Komisji Geografii Komunikacji PTG Transport Geography Papers of Polish Geographical Society $21(1) / 2018$

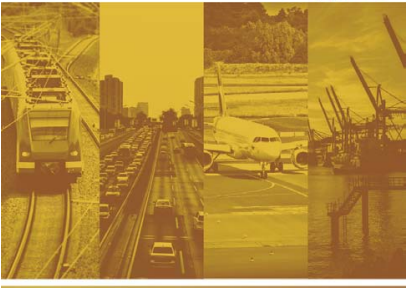

\section{Prace Komisji Geografii Komunikacji PTG}

$2018,21(1), 9-16$

DOI 10.4467/2543859XPKG.18.001.9181

Otrzymano (Received): 17.05.2017

Otrzymano poprawioną wersję (Received in revised form): 05.07.2017

Zaakceptowano (Accepted): 05.07.2017

Opublikowano (Published): 30.03.2018

\title{
NARROW-GAUGE RAILWAYS IN SLOVAKIA AND THEIR USE FOR TOURISM PURPOSES
}

\section{Koleje wąskotorowe na Słowacji i ich wykorzystanie dla celów turystycznych}

\section{Daniel Michniak}

Institute of Geography, Slovak Academy of Sciences, Štefánikova 49, 81473 Bratislava, Slovak Republic

e-mail: geogmich@savba.sk

\section{Citation:}

Michniak D., 2018, Narrow-gauge railways in Slovakia and their use for Tourism purposes, Prace Komisji Geografii Komunikacji Polskiego Towarzystwa Geograficznego, 21(1), 9-16.

Abstract: Narrow-gauge railways represent one of the most important chapters in history of railway transport in Slovakia. They had a significant position in the economic development of many regions in Slovakia mainly in the first part of the $20^{\text {th }}$ century. Forest or field railways successively lost their original function. Many of them were abandoned and disassembled, but in some cases they have found new function and they serve for the purposes of tourism. The aim of this article is to present existing narrow-gauge railways in Slovakia and analyse their use for purposes of tourism. Particular attention is devoted to the best examples of their functioning in Slovakia - the Čiernohronská Railway, the Kysuce-Orava Forest Railway and the Tatra Electric Railways.

Key words: narrow-gauge railways, Slovakia, tourism 


\section{Introduction}

Narrow-gauge railways (with a track gauge narrower than the $1,435 \mathrm{~mm}$ of standard gauge railways) had an important position in the economic development of many regions in Slovakia mainly in the first part of the $20^{\text {th }}$ century (see e.g. Kubáček, 1999; Bílek, 2000). They served as forest, field or industrial railways for the transport of materials (wood, sugar beet ...) to the processing factories or to the main standard-gauge railway tracks for further transport. Similar situation was in the Czech Republic (see e.g. Bauer, 2003), Poland (see e.g. Ciechański, 2007, 2013; Bebenow, 2015) Romania (Turnock, 2001; Muica, Turnock, 2003) and other countries. After the Second World War, the importance of road transport had grown and the role of narrow-gauge railways decreased. Finally, many narrow-gauge railways have lost their original function. Some of them were abandoned and disassembled, but in some cases they have found new function and they serve for the purposes of tourism. There were also narrow-gauge railways that from the beginning of their operation served for transport of passengers in areas that are attractive four many tourists (the Tatra Electric Railways) and narrow-gauge railways constructed for children and youth that should attract future railwaymen. The aim of this article is to present existing narrowgauge railways in Slovakia and analyse their use for purposes of tourism. Particular attention is devoted to the Čiernohronská Railway, the Kysuce-Orava Forest Railway and the Tatra Electric Railways, which represent best examples of their functioning in Slovakia. Their role is in transport of tourist within the tourist region or tourist attraction and in these cases transport itself can be regarded as a tourism experience.

\section{Research of the narrow-gauge railways and their role in tourism}

There are many studies that deal with the relationship between railway transport and tourism. Many scholars have studied the railway heritage and its importance for tourism (e.g. Halsall, 2001; Hörz, Richter, 2011; Conlin, Bird, 2014; Bebenow, 2015). According to Boughey (2013), when some railway routes have become obsolete for transport, there is an opportunity to use them for the development of tourism in the form of leisure-oriented transport, or the conservation of engineering structures or sites retained for nature, general amenity, historic environments, or contributions to the landscape.

Heritage railways tourism is a complex thing and has to deal with many issues as: (a) preservation versus commercialization and the related issues of com-modification and replication; (b) the financing of heritage attraction development and the operation and maintenance of the attractions; (c) skill retention and training in vanishing trades and crafts; (d) land and infrastructure ownership; (e) health and safety of employees, volunteers and visitors; ( $f$ ) and the now ubiquitous focus on sustainability in all its varied facets (Conlin, Bird, 2014).

According to Bebenow (2015) a geographic location largely affects the successful functioning of the individual tourist attractions connected with railways. The perspectives for development have predominantly railways and attractions located in interesting tourist regions and in the vicinity of large urban agglomerations. Responsible local governments should also contribute to maintenance costs and investment in heritage railways. Without the financial interventions of local governments, even railways that are very popular with tourists can become subject to liquidation. It is necessary to transform railways with a high tourism potential to the high quality tourist products that are well organised by staff of technicians and specialists in the area of tourism. Cooperation with other subjects in the field of tourism is also inevitable (legislation concerning tourism, local government, local tourist organizations, NGOs and operators of other tourist railways).

Functioning of heritage railways is dependent on volunteers, enthusiasts and railway lovers that help in various areas of such complex issue as heritage railways tourism is. Rhoden et al. (2009) identified six motivational dimensions of volunteers that were altruism, for me (work substitute), social/affiliative, instrumental (hobbies), for me (relaxation/change) and instrumental (skills).

\section{Narrow-gauge railways in Slovakia}

Narrow-gauge railways can be divided into groups according to their original function (e.g. forest, field, industrial, tourist).

Forest narrow-gauge railways represent one of the most important chapters in history of railway transport in Slovakia. Their total length at the time of greatest development in the first half of the $20^{\text {th }}$ century reached nearly $1,200 \mathrm{~km}$ in 40 localities. They were used for transport of wood from the mountain valleys to the main railway lines or to the wood processing factories. The largest systems of forest railways with the length of more than $100 \mathrm{~km}$ were located near Hronec (current Čiernohronská Forest Railway), in Orava and Kysuce region (Kysuce-Orava Forest Railway) and near Liptovský Hrádok (Považská Forest Railway). 
Field (agricultural) narrow-gauge railways were built in the beginning of the 20th century in lowland agricultural areas of southern Slovakia. They served for transport of agricultural products (mainly sugar beet) from the places of production to the processing plant (refinery). Four extensive field rail systems gradually arose around large sugar factories in Pohronský Ruskov (65 km), Šurany (75 km), Trnava (60 $\mathrm{km})$ and Sládkovičovo $(100 \mathrm{~km})$ in southern Slovakia.

Tourist narrow-gauge railways are represented by the Košice children historic railway built in 1956 as a Pioneer railway that served for training and motivation of young railwaymen.

Electric narrow-gauge railways were built in the Tatra Mountains region and near Trenčín, where the Trenčianska electric railway connected the spa town of Trenčianske Teplice with the main railway track Bratislava-Žilina-Košice. These railways served for the transport of passengers and tourists and have had also tourist function ${ }^{1}$.

In 2017 there were only a few narrow-gauge railways in Slovakia (see Fig. 1 and Tab 1). greenways as alternative environmentally friendly communication systems. An example of a greenway is the Ružomberok-Korytnica cycling route $(23 \mathrm{~km}$ long) that runs mostly along the original route of the former narrow-gauge railway.

\section{The Čiernohronská Railway}

History of Čiernohronská railway began in 1908 when the first section of the track from Hronec to Čierny Blh (now Čierny Balog) was built. In the past it was the largest forest railway system in Slovakia with 132 km of tracks (Fig. 2).

The railway was in the regular operation until 1982, when its length was $36 \mathrm{~km}$. After its closure, it gained heritage status and had undergone restoration works during the following decade. The railway transport was restored in 1992 between Čierny Balog and Vydrovská valley and from Hronec to Čierny Balog in 1993 for purposes of transport of tourists. The Association of the local communities "Čierny Hron microregion" is the owner and operator

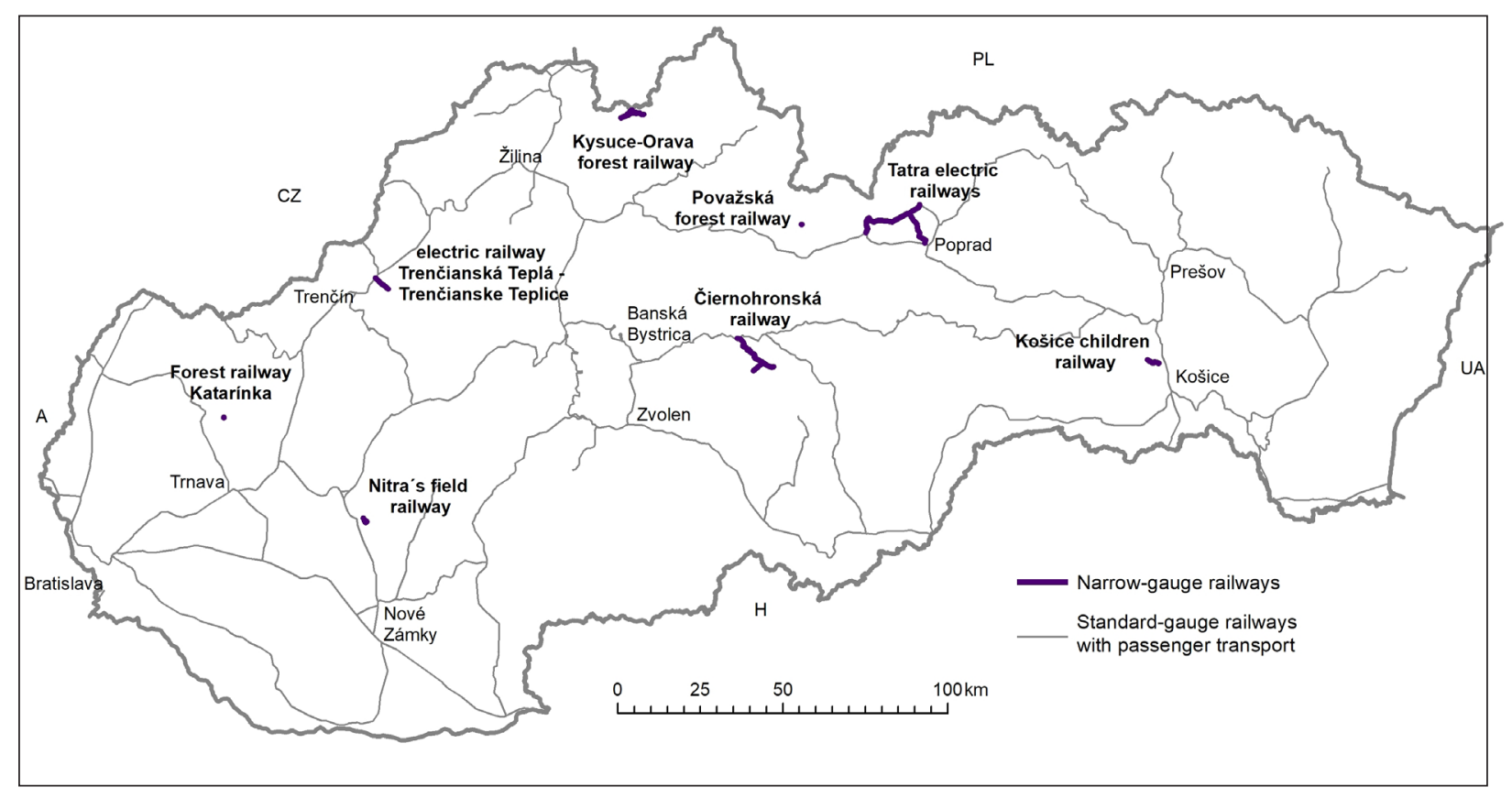

Fig. 1. Narrow-gauge railways in Slovakia with tourist function in 2017.

Source: own elaboration.

In the case of abandoned former narrowgauge railway tracks, it is possible to use them for the development of tourism in a form of

Tram network in Bratislava with the gauge $1,000 \mathrm{~mm}$ is also a narrow-gauge electric railway but it was not included to the group of railways that have mainly tourist function. Tram network in Bratislava serves mainly for public city transport. of Čiernohronská railway since 1995. The carrier Čiernohronská railway, a non-profit organization, is the provider of transport and public services since 2001. The operation is provided on renovated sections of track from Chvatimech to Čierny Balog, Vydrovská Valley and to Dobroč (since 2012), all together $19 \mathrm{~km}$. The number of passengers on railway has grown to more than 100 thousand in the period 2012-2016 
Tab. 1. Narrow-gauge railways in Slovakia with tourist function

\begin{tabular}{|c|c|c|c|c|c|c|c|}
\hline $\begin{array}{l}\text { Narrow-gauge } \\
\text { railways }\end{array}$ & $\begin{array}{l}\text { Original } \\
\text { function }\end{array}$ & $\begin{array}{l}\text { Maximum } \\
\text { length }(\mathrm{km})\end{array}$ & Operation & $\begin{array}{l}\text { Gauge } \\
(\mathrm{mm})\end{array}$ & $\begin{array}{l}\text { Lenght } \\
(\mathrm{km})\end{array}$ & $\begin{array}{c}\text { Tourist } \\
\text { function }\end{array}$ & Operator \\
\hline Čiernohronská Railway & forest & 132.0 & 1909-1982 & 760 & 20.0 & 1992 & Čiernohronská železnica, n.o. \\
\hline $\begin{array}{l}\text { Kysuce - Orava Forest } \\
\text { Railway }\end{array}$ & forest & 110.0 & $1915-1971$ & 760 & 11.3 & 1995 & $\begin{array}{l}\text { Kysucké múzeum v Čadci a Oravské } \\
\text { múzeum P.O. Hviezdoslava }\end{array}$ \\
\hline Považská Forest Railway & forest & 104.0 & $1912-1972$ & 760 & 0.1 & 2004 & $\begin{array}{l}\text { Spoločnost' pri Považskej lesnej } \\
\text { železnici, o.z. }\end{array}$ \\
\hline Nitrianska Field Railway & agricultural & 64.0 & 1895-1971 & 760 & 2.6 & 1985 & $\begin{array}{l}\text { Slovenské pol'nohospodárske } \\
\text { múzeum }\end{array}$ \\
\hline Forest Railway Katarínka & $\begin{array}{l}\text { industrial and } \\
\text { forest }\end{array}$ & 70.0 & 1903-1964 & 600 & 0.2 & 2002 & $\begin{array}{l}\text { Združenie na záchranu lesných } \\
\text { železníc Slovenska, o.z. }\end{array}$ \\
\hline $\begin{array}{l}\text { Košice Children Historic } \\
\text { Railway }\end{array}$ & tourism & 3.9 & 1956- & 1,000 & 3.9 & 1956 & Detská železnica Košice, o.z. \\
\hline Trenčianska Electric Railway & $\begin{array}{l}\text { passenger } \\
\text { transport and } \\
\text { tourism }\end{array}$ & 5.5 & 1909-2011 & 760 & 5.5 & 2013 & Trenčianska elektrická železnica, n. o. \\
\hline Tatra Electric Railways & $\begin{array}{l}\text { passenger } \\
\text { transport and } \\
\text { tourism }\end{array}$ & 35.0 & $1908-$ & 1,000 & 35.0 & 1908 & Železničná spoločnost' Slovensko, a.s. \\
\hline Cog Railway & $\begin{array}{l}\text { passenger } \\
\text { transport and } \\
\text { tourism }\end{array}$ & 4.8 & $1896-1933$ & 1,000 & 4.8 & 1969 & Železničná spoločnost' Slovensko, a.s. \\
\hline $\begin{array}{l}\text { Starý Smokovec - Hrebienok } \\
\text { Funicular }\end{array}$ & tourism & 1.9 & $1908-$ & 1,000 & 1.9 & 1908 & Tatry Mountain Resorts, a.s. \\
\hline
\end{tabular}

Source: own elaboration on the basis of Michniak (2016).

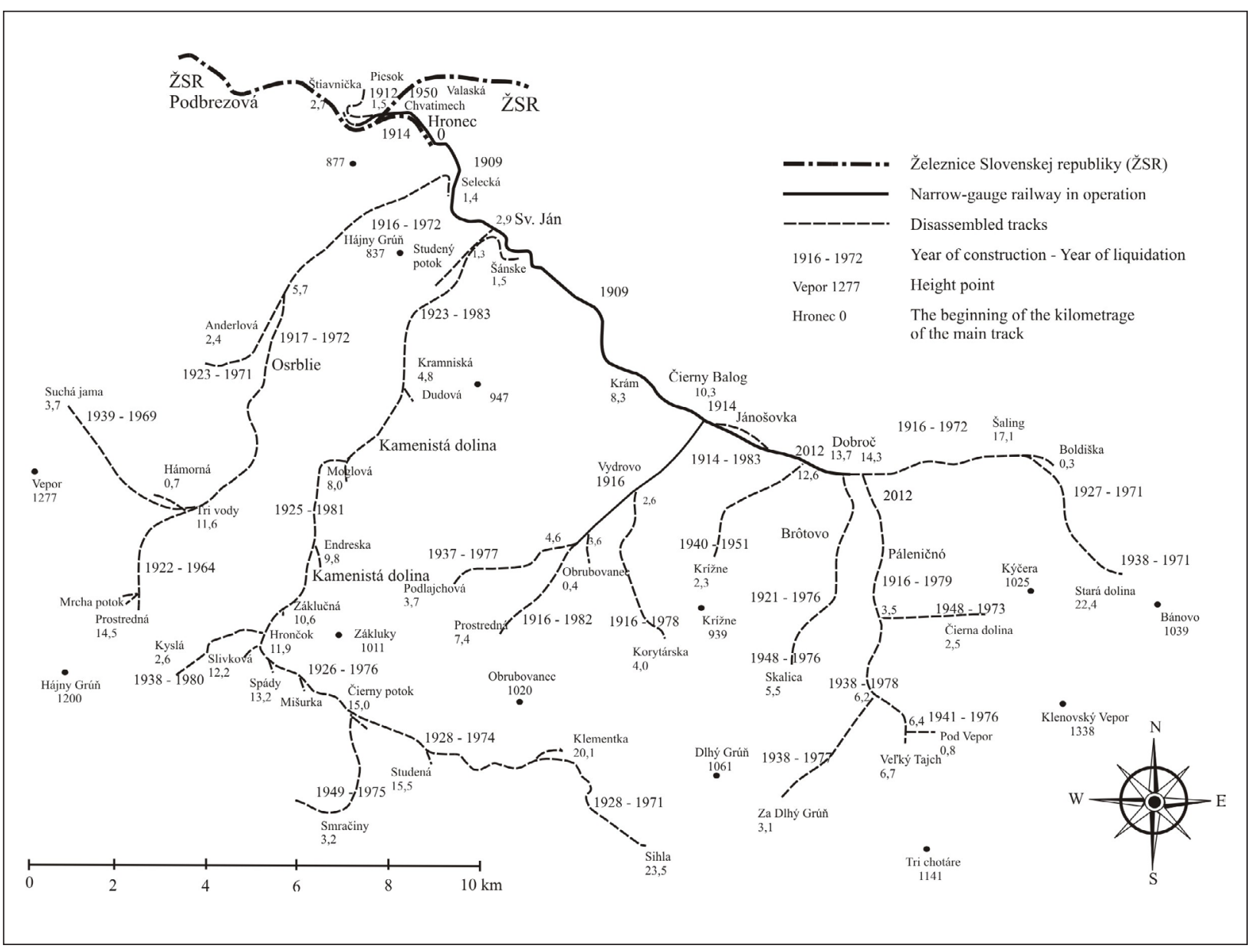

Fig. 2. Tracks of the Čiernohronská Railway.

Source: own elaboration on the basis of the Čiernohronská železnica, http://www.chz.sk. 
(Fig. 3). The Čiernohronská railway is in operation all year round, but summer season is evidently dominant. A visit of the Čiernohronská railway can be combined with a visit of the Forestry Open-Air Museum Vydrovská valley (established in 2002) and both tourist attractions benefit from their position close to each other. interesting part of the former narrow-gauge zig-zag logging forest railway which overcomes difference in altitude $(217.69 \mathrm{~m})$ on a relatively short section (direct distance 1,500 meters) has been preserved.

Operation of the Historical Logging Switchback Railway in Nová Bystrica-Vychylovka (Kysuce side) narrow-gauge railways for tourists started in 1996

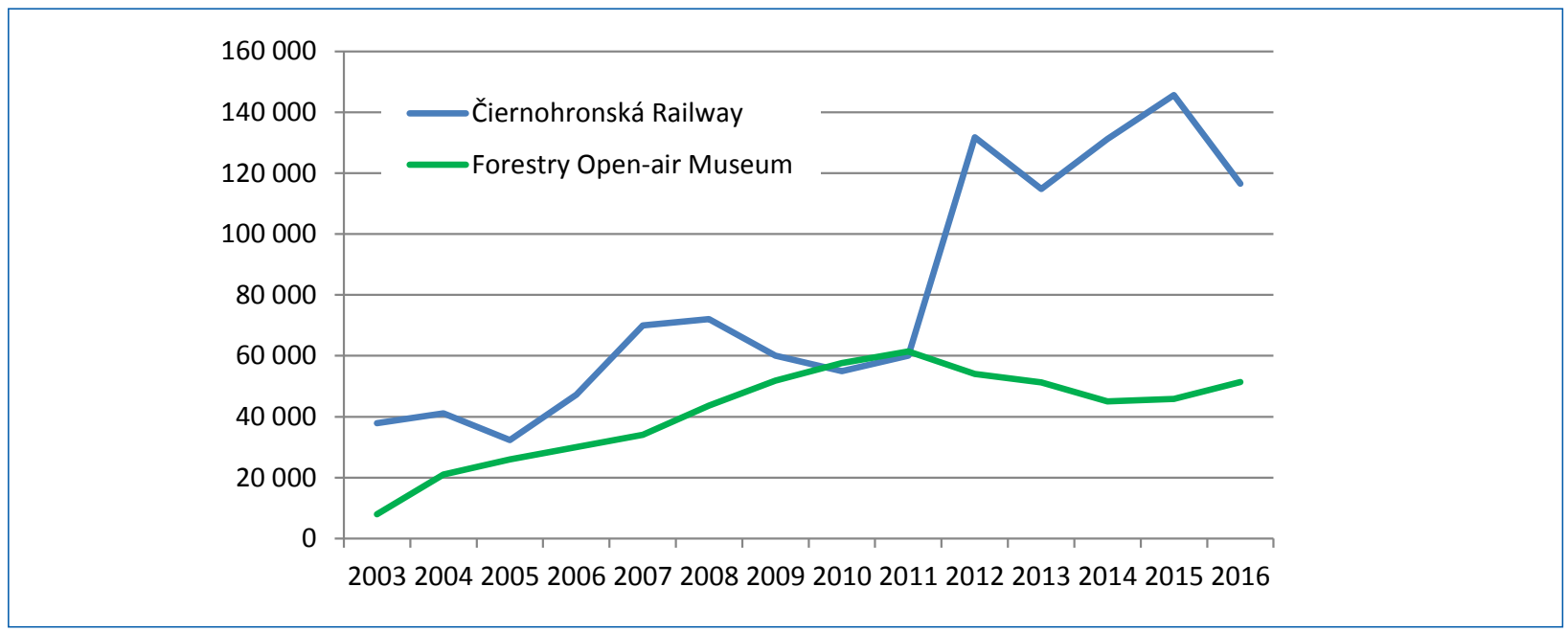

Fig. 3. Number of passengers on the Čiernohronská Railway and the number of visitors of the Forestry Open-Air Museum.

Source: own elaboration on the basis of data from the Čiernohronská železnica, http://www.chz.sk and Forestry open-Air museum.

\section{The Kysuce - Orava Forest Railway}

The narrow-gauge forest railway was in operation in the period 1915-1971. Two separated forest railway systems located in Kysuce and Orava regions were connected in 1926. In 1971, the railway was disassembled, except of an $8 \mathrm{~km}$ section from Chmúra to Tanečník (Fig. 4). In this way the technically most and on the Orava Forest Railway in Oravská Lesná (Orava side) in 2008. There are two operators of the railway - Kysuce Museum and Orava Museum which have the same establisher - both reporting to the Self-Administrative Region of Žilina.

Connection of these railways has been restored in 2013 and the trains between these two parts were in operation in summer seasons 2015 and 2016. While

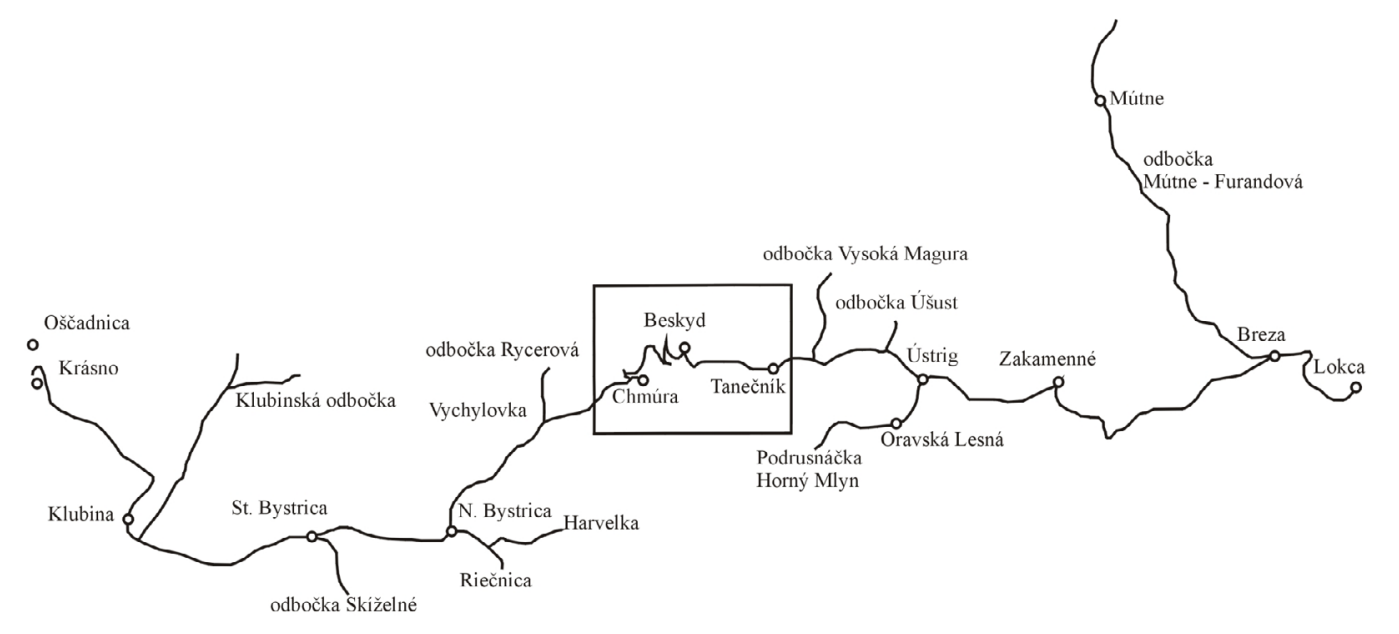

Fig. 4. Tracks of the Kysuce-Orava Forest Railway in operation in 1926.

Source: the Kysuce Museum, http://www.kysuckemuzeum.sk/. 
the Kysuce part of the railway operates only from May to October that of Orava operates all year round.

The visitors may visit the Open Air Museum of Vychylovka as a part of the Kysuce Museum opened in 1981 because the Kysuce part of the railway crosses the premises of the Museum. The number of visitors of the Kysuce-Orava Forest Railway has grown substantially since 2010 to nearly 90 thousands of passengers in 2016 (Fig. 5). Further 3.5 thousands passengers have used special trolley for transport through the switchback system since 2015. railway Tatranská Štrba-Štrbské Pleso and The Starý Smokovec- Hrebienok funicular. The cog railway Tatranská Štrba-Štrbské Pleso $(4.8$ km) worked in the years 1896 and 1933 and then since 1969. The Starý Smokovec-Hrebienok funicular has been in operation since 1908.

Trains of the Tatra Electric Railways are run with high frequency (approx. every hour) from early morning to late evening hours. The timetable is coordinated with other trains on the railway track Košice-Poprad-Žilina. Advantages of the Tatra

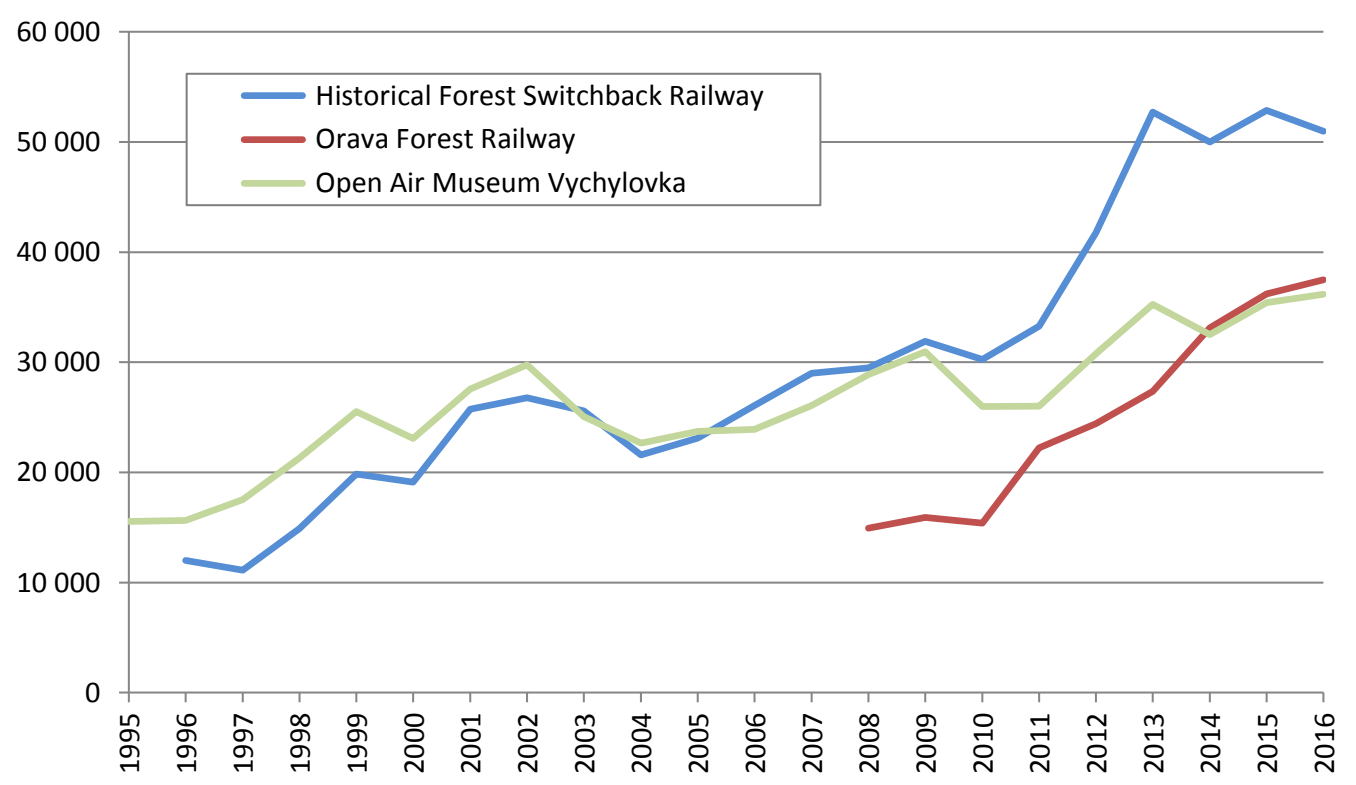

Fig. 5. Number of visitors of the Kysuce-Orava Forest Railway and the Open Air Museum of Vychylovka in 1995-2016.

Source: own elaboration on the basis of data from the Kysuce Museum and the Orava Museum.

\section{The Tatra Electric Railways}

This sustainable form of transport provides connections within the High Tatras region both for the inhabitants (e.g. commuting to school and work) as well as tourists going to the most attractive regions of the Slovak Tatras. It is the single track narrow-gauge electric railway operated by state railway carrier in Slovakia the Železničná spoločnost' Slovensko, a.s. (ZSSK).

These railways have a long history. Operation on the railway track Poprad-Starý Smokovec started in 1908; on the track section Starý SmokovecTatranská Lomnica in 1911 and on the track section Starý Smokovec - Štrbské Pleso in 1912 (Fig. 6). These railways are supplemented by the cog
Electric Railways include the possibility to transport large numbers of passengers and its ecological character. Transport on the Tatra Electric Railways is included into "Tatry Card" that offers also other benefits to the visitors of the High Tatras region.

The number of passengers (Fig. 7) decreased to the minimum in 2009-2010 (approx. 1.5 mill.). The introduction of the zero-fare public rail transport services for selected categories of passengers (students and seniors) transport since 17.11.2014 has had an impact on the change in transport behaviour of passengers and has led to an increase in transport figures (number of passengers, transport performance in passkm). The number of passengers has increased by 600 hundred thousand in two years (2014-2016), what represents 30\% growth rate. 


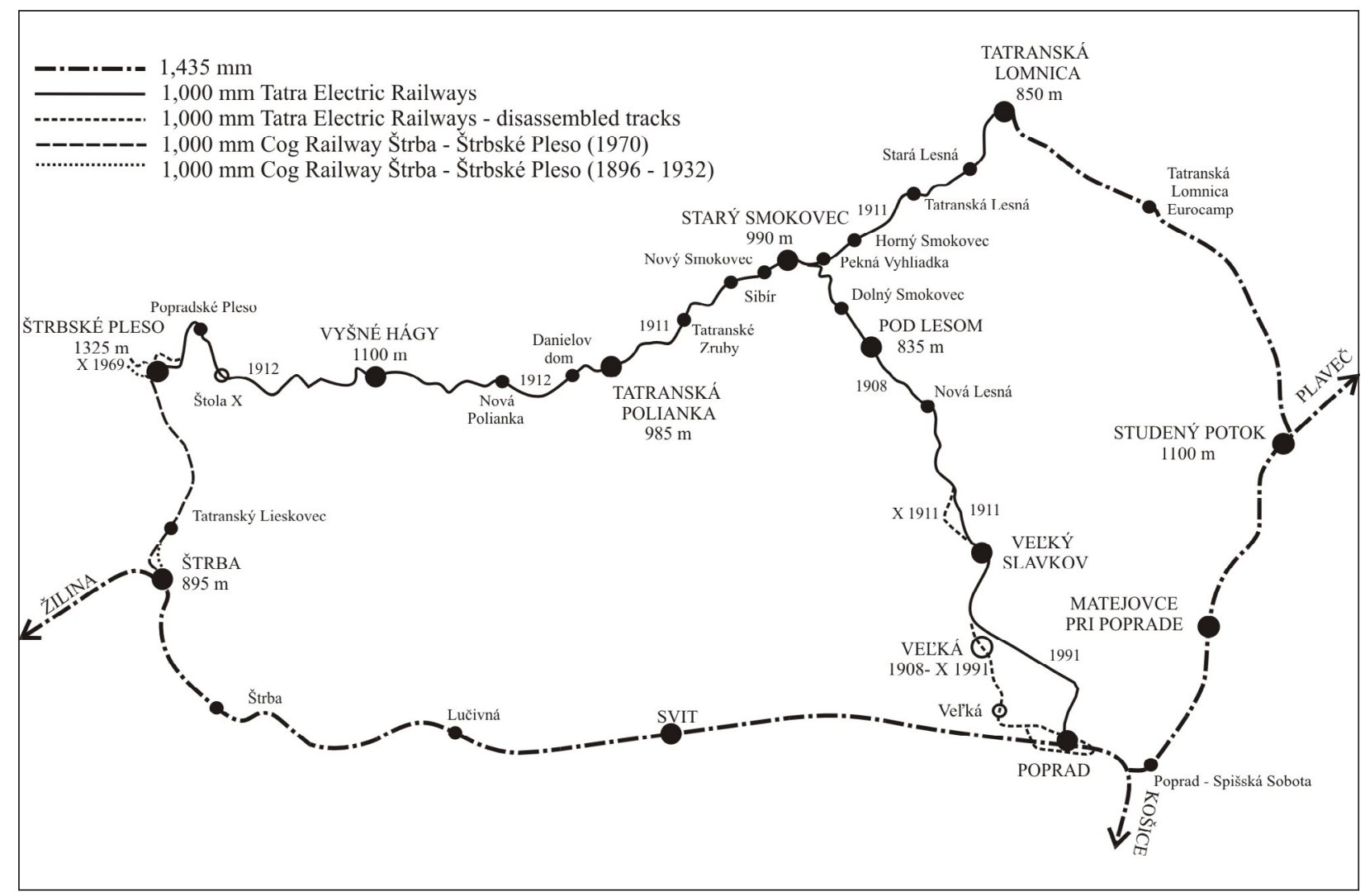

Fig. 6. Tracks of the Tatra Electric Railways.

Source: own elaboration on the basis of Beňák, 2008.

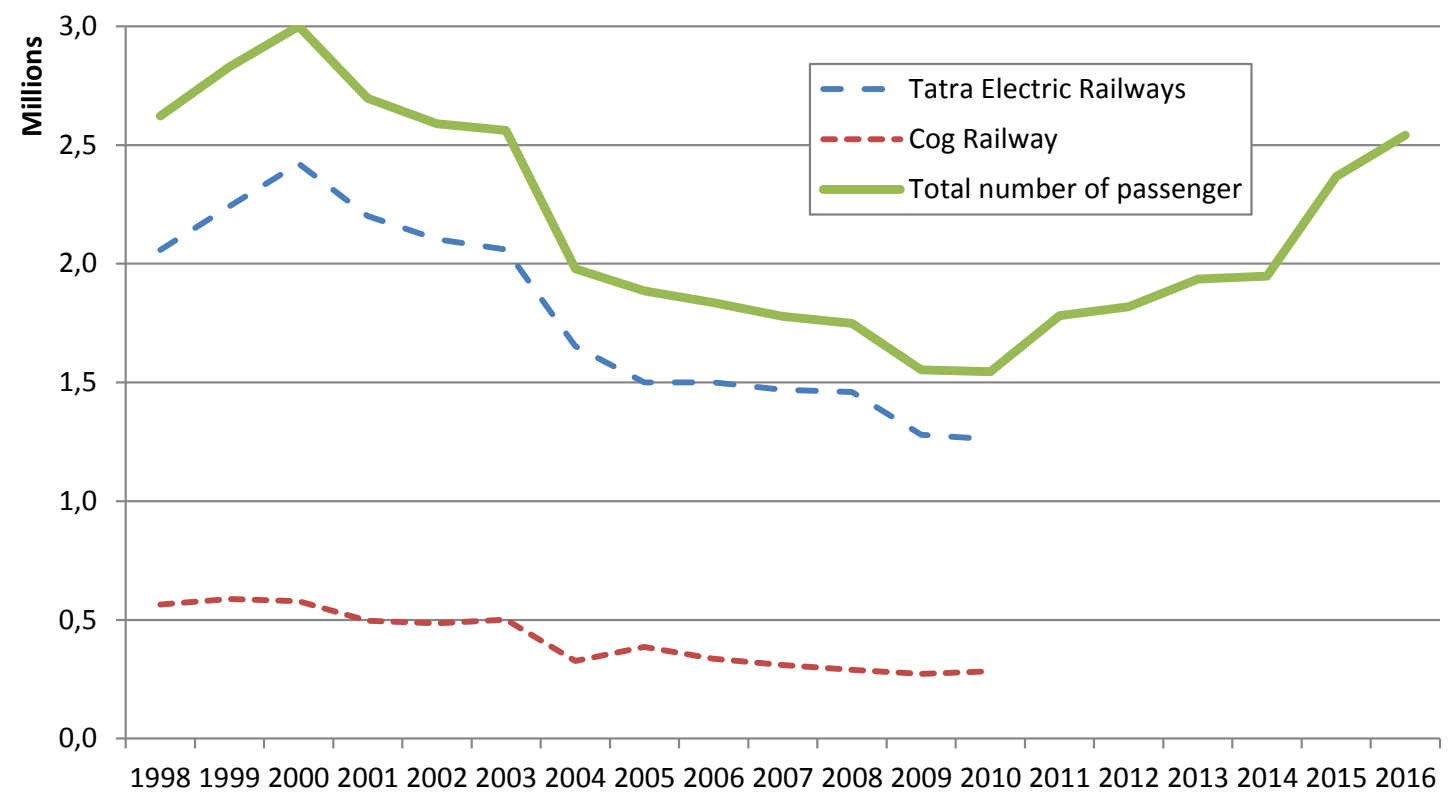

Fig. 7. Number of passengers on the Tatra Electric Railways and on the Tatranská Štrba-Štrbské Pleso Cog Railway². Source: own elaboration based on the basis of data from ZSSK - Railway Company Slovakia.

2 Data for the years 2011-2016 for the Tatra Electric Railways and the Cog Railway are given together, since the change in pricing policy from 01.11.2011 merged these closed tariff systems into a single tariff system. 


\section{Conclusions}

The only chance for further exploitation of the narrow-gauge railways, which lost their original function in the second half of the $20^{\text {th }}$ century, was their change to the tourist attraction. Narrow-gauge railways represent an important segment in rail tourism in Slovakia. There are some good examples of their use in the tourism sector. The Čiernohronská Forest Railway and the Kysuce-Orava Forest Railway represent a successful operation of the former forest narrow-gauge railways for tourism purposes. During last few years they attract more than 200,000 passengers a year. The visitors of the Čiernohronská railway can visit also the Forestry Open-Air Museum Vydrovská Valley. The Kysuce-Orava Forest Railway combines the railway heritage (a unique switchback railway) with the cultural heritage (the Vychylovka Open-Air Museum, the Museum of the Kysuce Village). A successful marketing strategy and the development of additional services for tourists lead to a growing number of visitors of these heritage railways. They have also potential for further development and growth of the number of tourists.

Other good example is the Tatra Electric Railways that combine passenger transport of local people with that of tourists in the High Tatras - the most attractive mountain area in Slovakia. A tact timetable, that is also coordinated with trains on the main railway track in Slovakia Košice-Poprad-Žilina-Bratislava, is an important factor of their successful operation. Growing number of passengers during last two years is also a result of the zero-fare public rail transport services policy of the state railway carrier.

\section{Acknowledgements}

This article has been prepared under project No. 2/0095/18 financed by the VEGA Grant Agency.

\section{References}

Bauer Z., 2003, Úzkorozchodné železnice v průmyslu a zemědělství, Corona, Praha.

Bebenow F., 2015, Turystyka kolejowa w Polsce, Bogucki Wydawnictwo Naukowe, Poznań.

Beňák L’., 2008, Ozubnicová železnice Štrba - Štrbské pleso, http://kubickaparabola.wz.cz/, [25.04.2017].

Bílek A., 2000, Lesné železnice na Slovensku, http://rail.sk/ skhist/lz/lz.htm, [25.04.2017].
Boughey J., 2013, From transport's golden ages to an age of tourism: L.T.C. Rolt, waterway revival and railway preservation in Britain, 1944-54. The Journal of Transport History, 34(1), 23-38.

Ciechański A., 2007, Koleje cukrownicze w Europie Środkowej, Prace Komisji Geografii Komunikacji PTG, 13, 221-242.

Ciechański A., 2013, Rozwój i regres sieci kolei przemysłowych w Polsce w latach 1881-2010, Prace Geograficzne 243, Institute of Geography and Spatial Organization Polish Academy of Sciences, Warszawa.

Conlin M.V., Bird R.B. (eds), 2014, Railway heritage and tourism: A global perspective, Channel View, Bristol.

Čiernohronská železnica, http://www.chz.sk [11.04.2017].

Halsall D.A., 2001, Railway heritage and the tourist gaze: Stoomtram Hoorn-Medemblik, Journal of Transport Geography, 9, 151-160.

Hörz P., Richter M., 2011, Preserved as technical monuments, run as tourist attractions. Narrow-gauge railways in the German Democratic Republic, The Journal of Transport History, 32(2), 192-213.

Kubáček J. (ed.), 1999, Dejiny železníc na území Slovenska, Železnice Slovenskej republiky, Bratislava.

Kysucké múzeum, http://www.kysuckemuzeum.sk [11.04.2017].

Michniak D., 2016, Role of railway transport in tourism: Selected problems and examples in Slovakia, Quaestiones Geographicae, 35(4), 107-120.

Muica N., Turnock D., 2003, The railway age in the Carpathian forests: a study of Romania, Geographica Pannonica, 7, 9-20.

Rhoden S., Ineson E.M., Ralston R., 2009, Volunteer motivation in heritage railways: a study of the West Somerset Railway volunteers, Journal of Heritage Tourism, 4(1), 19-36.

Turnock D., 2001, Railways and economic development in Romania before 1918, Journal of Transport Geography, 9(2), 137-150. 